medRxiv preprint doi: https://doi.org/10.1101/2020.05.26.20114140; this version posted May 28, 2020. The copyright holder for this preprint (which was not certified by peer review) is the author/funder, who has granted medRxiv a license to display the preprint in perpetuity. It is made available under a CC-BY-NC-ND 4.0 International license .

Mental health outcomes and associations during the coronavirus disease 2019 pandemic: A cross-sectional survey of the US general population

Bella Nichole Kantor; ${ }^{1}$ Jonathan Kantor, MD, MSCE, MA $2,3,4,5^{*}$

1. Harvard Extension School, Harvard University, Cambridge, MA, 02138 USA

2. Center for Global Health, University of Pennsylvania Perelman School of Medicine, Philadelphia, PA, 19104 USA

3. Center for Clinical Epidemiology and Biostatistics, University of Pennsylvania Perelman School of Medicine, Philadelphia, PA, 19104 USA

4. Department of Dermatology, University of Pennsylvania Perelman School of Medicine, Philadelphia, PA, 19104 USA

5. Florida Center for Dermatology, P.A., St Augustine, FL, 32080 USA

Abstract

Pandemic coronavirus disease 2019 (COVID-19) may lead to significant mental health stresses, potentially with modifiable risk factors. To determine the presence of and magnitude of associations between baseline associations and anxiety and depression in the US general population, we performed an internet-based cross-sectional survey of an age-, sex-, and racestratified representative sample from the US general population. Degrees of anxiety, depression, and loneliness were assessed using the 7-item Generalized Anxiety Disorder scale (GAD-7), the 9-item Patient Health Questionnaire (PHQ-9), and the 8-item UCLA Loneliness Scale, respectively. Unadjusted and multivariable logistic regression analyses were performed to determine associations with baseline demographic characteristics. A total of 1,005 finished surveys were returned of the 1,020 started, yielding a completion rate of $98.5 \%$ in the survey panel. The mean (SD) age of respondents was 45 (16), and $494(48.8 \%)$ were male. Baseline demographic data were similar between those that were $(n=663,66.2 \%)$ and were not $(n=339$, $33.8 \%$ ) under a shelter in place/ stay at home order, with the exception of sex and geographic location. Overall, 264 subjects (26.8\%) met criteria for an anxiety disorder based on a GAD-7 cutoff of 10; a cutoff of 7 yielded 416 subjects (41.4\%) meeting clinical criteria for anxiety. On multivariable analysis, male sex (OR $0.65,95 \% \mathrm{Cl}[0.49,0.87])$ and living in a larger home (OR $0.46,95 \% \mathrm{Cl}[0.24,0.88])$ were associated with a decreased odds of meeting anxiety criteria. Rural location (OR 1.39, 95\% Cl [1.03, 1.89]), loneliness (OR 4.92, 95\% Cl [3.18, 7.62]), and history of hospitalization (OR 2.04, 95\% Cl [1.38, 3.03]), were associated with increased odds of meeting anxiety criteria. 232 subjects (23.6\%) met criteria for clinical depression. On multivariable analysis, male sex (OR $0.71,95 \% \mathrm{Cl}[0.53,0.95])$, increased time outdoors (OR $0.51,95 \% \mathrm{Cl}[0.29,0.92])$, and living in a larger home (OR $0.35,95 \% \mathrm{Cl}[0.18,0.69])$, were associated with decreased odds of meeting depression criteria. Having lost a job (OR 1.64, 95\% $\mathrm{Cl}[1.05,2.54])$, loneliness (OR 10.42, 95\% Cl [6.26, 17.36]), and history of hospitalization (OR $2.42,95 \% \mathrm{Cl}[1.62,3.62])$, were associated with an increased odds of meeting depression criteria. Income, media consumption, and religiosity were not associated with mental health outcomes. Anxiety and depression are common in the US general population in the context of the COVID-19 pandemic, and are associated with potentially modifiable factors.

NOTE: This preprint reports new research that has not been certified by peer review and should not be used to guide clinical practice. 1 
medRxiv preprint doi: https://doi.org/10.1101/2020.05.26.20114140; this version posted May 28, 2020. The copyright holder for this preprint (which was not certified by peer review) is the author/funder, who has granted medRxiv a license to display the preprint in perpetuity. It is made available under a CC-BY-NC-ND 4.0 International license .

\section{Mental health outcomes and associations during the coronavirus disease 2019 pandemic: A cross-sectional survey of the US general population}

The Coronavirus disease 2019 (COVID-19) pandemic has led to unprecedented levels of movement restriction, job losses, and economic uncertainty in the United States and around the world. ${ }^{1}$ Concerns regarding illness, death, and the death of loved ones may be compounded by financial uncertainty, as reports of mass unemployment with variable international governmental responses circulate. ${ }^{2}$

Mental health outcomes have been associated with pandemics in the past. ${ }^{3-5}$ While there has been a rapid response to the COVID-19 pandemic in terms of nonpharmaceutical interventions, vaccine development, and medical support, little comprehensive planning has been performed to predict and respond to the possible mental health crisis that could emerge from the pandemic, and the only data available on general public responses to the pandemic are in Chinese populations. ${ }^{6,7}$ These data are echoed by recent research that has suggested that healthcare workers have a significant burden of mental health challenges in the face of COVID$19 .^{8}$ Moreover, pandemics and other natural disasters may disproportionately affect those with underlying mental illness. ${ }^{9}$

We therefore sought to investigate the prevalence of anxiety and depression in the general US population in the context of the early COVID-19 pandemic, and explore associations of these mental health outcomes with loneliness (of particular concern given enhanced social distancing and isolation), health status, socioeconomic status, residence size, time spent outdoors, and other baseline demographic characteristics. A better understanding of the prevalence of these mental health outcomes and their putative risk factors may help guide public policy in establishing improved guidelines for those required to stay at home.

\section{Methods}

\section{Study Design}

This study is a cross-sectional, internet-based survey performed via age, sex, and race stratification, conducted between March 29, 2020 and March 31, 2020. Responses to all survey questions were recorded (Supplemental file). This study was deemed exempt by the Ascension Health institutional review board.

We developed an online survey using the Qualtrics platform (Qualtrics Corp, Provo, Utah) after iterative online pilot testing. The survey was distributed to a representative sample of the US population using Prolific Academic (Oxford, United Kingdom), an established platform for academic survey research. ${ }^{10}$ Respondents were rewarded with a small payment (<US\$1). Participants provided consent and were permitted to terminate the survey at any time. All surveys were anonymous and confidential, with linkages between data performed using a 24character alphanumeric code. The investigators had no access to identifying information at any time. 
medRxiv preprint doi: https://doi.org/10.1101/2020.05.26.20114140; this version posted May 28, 2020. The copyright holder for this preprint (which was not certified by peer review) is the author/funder, who has granted medRxiv a license to display the preprint in perpetuity. It is made available under a CC-BY-NC-ND 4.0 International license .

\section{Participants}

This internet-based survey was stratified by age, sex, and race to reflect the makeup of the general US population. Sample size calculations were conducted for the primary endpoint of detecting a $10 \%$ difference in the Generalized Anxiety Disorder-7 scale (GAD-7) between those that were and were not under a stay at home order at the time of survey completion. 682 subjects (341 per group) would be adequate to detect a 10\% change in GAD-7 with $80 \%$ power and with an alpha of 0.05 , assuming a baseline GAD-7 mean of 11.6 with a standard deviation of 5.4 and assuming equal group sizes. ${ }^{11}$ We inflated our sample size to 1,000 given that approximately $2 / 3$ of the US was under stay at home orders at the time of survey initiation and given uncertainty regarding changes in those orders over the duration of the survey, as well as to permit subgroup analyses.

\section{Outcome Measures}

Demographic information was self-reported by respondents. Responses to a battery of questions regarding attitudes to the COVID-19 pandemic, were collected using Likert scales.

For our main outcome measures, anxiety and depression, validated scales were used. Anxiety was assessed using the GAD-7, a validated self-report scale for anxiety, with scores ranging from 0 (no anxiety) to 21 (extreme anxiety). Prior psychometric research suggested cutoffs as 04 (no anxiety); 5-9 (mild anxiety); 10-14 (moderate anxiety); and 15-21 (severe anxiety). ${ }^{8,11}$

Depression was assessed with the Patient Health Questionnaire-9 (PHQ-9), a validated measure for clinical depression. ${ }^{12}$ Scores range from 0 (no depression) to 27 (severe depression). Prior psychometric research has suggested cutoffs as 0-4 (no depression); 5-9 (mild depression); $10-$ 14 (moderate depression); and 15-27 (severe depression). ${ }^{8,13}$

Loneliness was quantified with the UCLA short-form loneliness scale (ULS-8), a validated measure of loneliness. ${ }^{14}$ Scores range from 8 (no loneliness) to 32 (extreme loneliness); no clinically meaningful cutoffs have been established psychometrically.

\section{Statistics}

Normally distributed baseline demographic data are presented as mean values with $95 \%$ confidence intervals $(\mathrm{Cl})$. Outcomes that were not normally distributed are presented as medians with interquartile ranges (IQR). T-tests and chi-squared tests were used as appropriate for baseline continuous and categorical variables. Subgroup comparisons of non-normally distributed data were performed using the Kruskal Wallis test. Unadjusted and multivariable (adjusting for age and sex, which are not modifiable confounders) logistic regression odds ratios of association were assessed between the dependent variables of anxiety or depression, presented as dichotomous outcomes using the established cutoffs of 10 for both the GAD-7 and PHQ-9, and putative risk factors.

All statistical analyses were performed using Stata 13 for Mac (Stata Corporation, College Station, Texas). 
medRxiv preprint doi: https://doi.org/10.1101/2020.05.26.20114140; this version posted May 28, 2020. The copyright holder for this preprint (which was not certified by peer review) is the author/funder, who has granted medRxiv a license to display the preprint in perpetuity. It is made available under a CC-BY-NC-ND 4.0 International license .

\section{Results}

Baseline Characteristics

Of the 1,020 subjects who were recruited, 1,005 finished the survey, yielding a completion rate of $98.5 \%$. The mean (SD) age of respondents was 45 (16), and $494(48.8 \%)$ of the respondents were male; baseline respondent characteristics are outlined in Table 1. Baseline demographic data were similar between those that were $(n=663,66.2 \%)$ and were not $(n=339,33.8 \%)$ under a shelter in place or stay at home order, with the exception of sex and geographic location (urban versus rural status). The median (IQR) ULS-8 score for loneliness was 16 (8), similar to baseline estimates from previous studies. ${ }^{14-16}$

\section{Anxiety}

The median (IQR) GAD-7 score was 5 (9), and 513 subjects (52.1\%) of subjects had at least mild anxiety. Overall, 264 subjects (26.8\%) met criteria for an anxiety disorder based on a GAD-7 cutoff of 10 (Table 2). Adopting a more liberal GAD-7 cutoff of 7, as used in a recent study on healthcare worker anxiety in the COVID-19 context, ${ }^{8}$ would yield 416 subjects $(41.4 \%)$ meeting clinical criteria for anxiety. Women $(p=0.002)$ and those living in rural areas $(p=0.041)$, reported more severe anxiety than men and those in urban areas, respectively.

Unadjusted logistic regression analysis demonstrated that men were less likely to meet criteria for anxiety (OR $0.67,95 \% \mathrm{Cl}[0.51,0.89])$ while those who lost their job (OR 1.61, 95\% $\mathrm{Cl}[1.45$, $2.45]$ ), had been hospitalized within the past 2 years (OR $1.86,95 \% \mathrm{Cl}[1.27,2.73]$ ), or were in the most lonely quartile (OR $5.39,95 \% \mathrm{Cl}[3.53,8.24]$ ), were more likely to meet criteria for anxiety. On multivariable analysis controlling for age and sex as confounders, male sex (OR $0.65,95 \% \mathrm{Cl}[0.49,0.87])$, and living in a larger home (OR $0.46,95 \% \mathrm{Cl}[0.24,0.88]$ ) were associated with a decreased odds of meeting anxiety criteria. Rural location (OR $1.39,95 \% \mathrm{Cl}$ $[1.03,1.89])$, loneliness (OR 4.92, 95\% Cl [3.18, 7.62]), and history of hospitalization within the past 2 years (OR $2.04,95 \% \mathrm{Cl}[1.38,3.03])$, were independent risk factors for meeting anxiety criteria (Table 3).

\section{Depression}

The median (IQR) PHQ-9 score was 4 (8), and 465 (47.3\%) of subjects reported at least mild depression by screening (Table 2). A total of 232 subjects (23.6\%) met criteria for clinical depression. Women $(p=0.008)$ and unmarried subjects $(p<0.0001)$ reported more severe depression than men and those who are married, respectively.

Unadjusted logistic regression analysis demonstrated that men were less likely to meet criteria for depression (OR $0.73,95 \% \mathrm{Cl}[0.55,0.98]$ ), while those who lost their job (OR $1.74,95 \% \mathrm{Cl}$ $[1.13,2.67])$, had been hospitalized within the past 2 years (OR $2.16,95 \% \mathrm{Cl}[1.47,3.17])$, or were in the most lonely quartile (OR 11.90, 95\% CI [7.21, 19.65]), were more likely to meet criteria for depression. On multivariable analysis controlling for age and sex as confounders, male sex (OR 0.71, 95\% Cl [0.53, 0.95]), increased time outdoors (OR 0.51, 95\% Cl [0.29, 0.92]), and living in a larger home (OR $0.35,95 \% \mathrm{Cl}[0.18,0.69])$ were associated with a decreased odds of meeting depression criteria. Having lost a job (OR 1.64, 95\% Cl [1.05, 2.54]), loneliness (OR 
medRxiv preprint doi: https://doi.org/10.1101/2020.05.26.20114140; this version posted May 28, 2020. The copyright holder for this preprint (which was not certified by peer review) is the author/funder, who has granted medRxiv a license to display the preprint in perpetuity. It is made available under a CC-BY-NC-ND 4.0 International license .

$10.42,95 \% \mathrm{Cl}[6.26,17.36])$, and history of hospitalization within the past 2 years (OR $2.42,95 \%$ $\mathrm{Cl}[1.62,3.62])$, were associated with meeting depression criteria (Table 3).

\section{Discussion}

In this first study of general US population mental health during the COVID-19 pandemic, we found high baseline levels of both anxiety and depression, independent of living under a shelter in place or stay at home order. More than half (52.1\%) of respondents had at least mild anxiety, and $47.3 \%$ of subjects had at least mild depressive symptoms. Adopting the cutoff of 7 on the GAD-7 score for anxiety, as used in a recent study on COVID-19, would yield 416 subjects $(41.4 \%)$ meeting clinical criteria for anxiety. This high burden of mental health concerns in the general population in the pandemic context suggests the need for further study and consideration for intervention.

Living in a larger home was associated with a reduced risk of both anxiety and depression; this effect was seen despite the lack of any association between anxiety or depression and household income and persisted when including income and number of household members into a multivariable model. Similarly, we found that increased time spent outdoors correlated with a reduction in depression (but not anxiety) risk, and those that spent more than an hour a day outdoors had approximately half the risk of depression as those that spent no time outdoors. This association of depression with time outdoors echoes prior research on access to green space access and its impact on mental health. ${ }^{17}$ Our finding that both larger living space and increased time spent outdoors correlate with a reduction in mental health burden may have actionable implications for public health initiatives and decisions regarding access to outdoor recreation areas during stay at home or shelter in place orders.

History of hospitalization, a rough measure of overall health status, was associated with an increased risk of both anxiety and depression. This effect persisted even when controlling for age and history of anxiety and depression, respectively, suggesting that those with a poorer health status may be at increased risk of adverse mental health outcomes in the context of the COVID-19 pandemic.

Media consumption, measured by the number of hours spent watching or reading about the pandemic, was not associated with the presence of anxiety or depression. Similarly, we did not detect significant associations between likelihood of meeting criteria for anxiety or depression and household income or religiosity on adjusted multivariable analyses.

Notably, we found that less than half of respondents had no anxiety; that is, more than half of subjects reported a level of anxiety that would at least be classified as mild. Conversely, 13.4\% of subjects demonstrated severe anxiety, a higher proportion than has been reported even in healthcare workers responding to pandemic COVID-19. ${ }^{8}$

Loneliness is an established risk factor for both anxiety and depression, ${ }^{15,18}$ and we found an approximately 5 - to 10 -fold increase in odds of anxiety and depression, respectively, with being in the highest loneliness quartile. As with those living in smaller homes with minimal access to 
medRxiv preprint doi: https://doi.org/10.1101/2020.05.26.20114140; this version posted May 28, 2020. The copyright holder for this preprint (which was not certified by peer review) is the author/funder, who has granted medRxiv a license to display the preprint in perpetuity.

the outdoors, loneliness can be seen as an independent risk factor for anxiety or depression in the context of the COVID-19 pandemic.

\section{Limitations}

This study has several limitations. First, as with any survey-based research, its generalizability may be limited. We used Prolific Academic for survey distribution in order to maximize our generalizability to the general US population by using an age-, sex-, and race-stratified survey panel design. As with any survey data, however, the sample willing to participate may not fully reflect the population of interest. Second, our study took place during the early phase of the COVID-19 pandemic, when shelter in place and stay at home orders were only just beginning. If anything, however, this underestimates the prevalence of anxiety and depression as these outcomes would only be expected to increase as restrictions persist, and highlights that even the anticipation of such restrictions may present a stressor. Third, as with any survey study, response bias and social desirability bias may play a role, though the anonymous survey design may help mitigate these concerns. Fourth, while our study relied on validated scales wherever possible, some survey questions were the product of pilot testing alone, and therefore their methodology-while consistent with the survey development literature-has not been fully vetted. Finally, and importantly, this cross-sectional study that lacks a comparator group cannot establish causation; therefore, we do not know whether the associations we describe are truly clinical risk factors.

\section{Conclusions}

In this first study of mental health outcomes in the US population during the COVID-19 pandemic, we found high rates of depression and anxiety, with the most profound mental health effects in women, those with a history of hospitalization over the past two years, those who were most lonely, and those living in smaller homes and (for depression) those spending the least time outdoors. 
medRxiv preprint doi: https://doi.org/10.1101/2020.05.26.20114140; this version posted May 28, 2020. The copyright holder for this preprint

(which was not certified by peer review) is the author/funder, who has granted medRxiv a license to display the preprint in perpetuity.

It is made available under a CC-BY-NC-ND 4.0 International license .

\section{References}

1. Wells CR, Sah P, Moghadas SM, et al. Impact of international travel and border control measures on the global spread of the novel 2019 coronavirus outbreak. Proceedings of the National Academy of Sciences of the United States of America. 2020.

2. Buehler K, Samandari H, Conjeaud O, Webanck L, Serino L, White O. Leadership in the time of coronavirus: COVID-19 response and implications for banks. McKinsey Insights. 2020.

3. Marshall H, Tooher R, Collins J, et al. Awareness, anxiety, compliance: Community perceptions and response to the threat and reality of an influenza pandemic. AJIC: American Journal of Infection Control. 2012;40(3):270-272.

4. Taha S, Matheson K, Cronin T, Anisman H. Intolerance of uncertainty, appraisals, coping, and anxiety: The case of the 2009 H1N1 pandemic. British Journal Of Health Psychology. 2014;19(3):pp592-605.

5. Wheaton M, Abramowitz J, Berman N, Fabricant L, Olatunji B. Psychological Predictors of Anxiety in Response to the H1N1 (Swine Flu) Pandemic. Cognitive Therapy and Research. 2012;36(3):210-218.

6. Lu D, Jennifer B. Public Mental Health Crisis during COVID-19 Pandemic, China. Emerging Infectious Disease journal. 2020;26(7).

7. Wang C, Pan R, Wan X, et al. Immediate Psychological Responses and Associated Factors during the Initial Stage of the 2019 Coronavirus Disease (COVID-19) Epidemic among the General Population in China. International Journal of Environmental Research and Public Health. 2020;17(5).

8. Lai J, Ma S, Wang Y, et al. Factors Associated With Mental Health Outcomes Among Health Care Workers Exposed to Coronavirus Disease 2019. JAMA Network Open. 2020;3(3):e203976-e203976.

9. Druss BG. Addressing the COVID-19 Pandemic in Populations With Serious Mental Illness. JAMA Psychiatry. 2020.

10. Peer E, Brandimarte L, Samat S, Acquisti A. Beyond the Turk: Alternative platforms for crowdsourcing behavioral research. Journal of Experimental Social Psychology. 2017;70:153-163.

11. Spitzer RL, Kroenke K, Williams JBW, Löwe B. A Brief Measure for Assessing Generalized Anxiety Disorder: The GAD-7. Archives of Internal Medicine. 2006;166(10):1092-1097.

12. Milette K, Hudson M, Baron M, Thombs BD. Comparison of the PHQ-9 and CES-D depression scales in systemic sclerosis: internal consistency reliability, convergent validity and clinical correlates. Rheumatology. 2010;49(4):789-796.

13. Beard C, Hsu KJ, Rifkin LS, Busch AB, Björgvinsson T. Validation of the PHQ-9 in a psychiatric sample. Journal of Affective Disorders. 2016;193:267-273.

14. Hays RD, Dimatteo MR. A short-form measure of loneliness. Journal of personality assessment. 1987;51(1):69.

15. Soh LK, Pang JS. The relationship between living with a spouse and mental health in the elderly population: Moderated mediation effects of loneliness and perceived problems. Clinical Medicine Insights: Psychiatry. 2019;10. 
16. Wiseman H, Guttfreund DG, Lurie I. Gender differences in loneliness and depression of university students seeking counselling. British Journal of Guidance \& Counselling. 1995;23(2):231-243.

17. Engemann K, Pedersen CB, Arge L, Tsirogiannis C, Mortensen PB, Svenning J-C. Residential green space in childhood is associated with lower risk of psychiatric disorders from adolescence into adulthood. Proceedings of the National Academy of Sciences of the United States of America. 2019;116(11):5188.

18. Domènech-Abella J, Mundó J, Haro JM, Rubio-Valera M. Anxiety, depression, loneliness and social network in the elderly: Longitudinal associations from The Irish Longitudinal Study on Ageing (TILDA). Journal of Affective Disorders. 2019;246:82-88. 
medRxiv preprint doi: https://doi.org/10.1101/2020.05.26.20114140; this version posted May 28, 2020. The copyright holder for this preprint (which was not certified by peer review) is the author/funder, who has granted medRxiv a license to display the preprint in perpetuity.

It is made available under a CC-BY-NC-ND 4.0 International license .

\begin{tabular}{|c|c|c|c|}
\hline \multirow[b]{3}{*}{ Characteristic } & \multicolumn{3}{|l|}{ No. (\%) } \\
\hline & \multirow[b]{2}{*}{ Total } & \multicolumn{2}{|c|}{ Under a shelter in place order } \\
\hline & & Yes & No \\
\hline Overall & $1005(100)$ & $681(66.8)$ & $389(33.2)$ \\
\hline \multicolumn{4}{|l|}{ Sex $^{*}$} \\
\hline Men & $494(48.8)$ & $310(46.1)$ & $184(54.3)$ \\
\hline Women & $518(51.2)$ & $363(53.9)$ & $155(45.7)$ \\
\hline \multicolumn{4}{|l|}{ Age, y } \\
\hline $18-30$ & $250(24.5)$ & $165(24.2)$ & $85(25.1)$ \\
\hline $31-40$ & $204(20.0)$ & $139(20.4)$ & $65(19.2)$ \\
\hline $41-50$ & $146(14.3)$ & $100(14.7)$ & $46(13.6)$ \\
\hline $51-60$ & $198(198.4)$ & $130(19.1)$ & $68(20.1)$ \\
\hline$>60$ & $222(21.8)$ & $147(21.6)$ & $75(22.1)$ \\
\hline \multicolumn{4}{|l|}{ Education level } \\
\hline$<$ High school & $11(1.1)$ & $8(1.2)$ & $3(0.9)$ \\
\hline High school & $117(11.7)$ & $67(10.1)$ & $50(14.8)$ \\
\hline Some college & $228(22.8)$ & $149(22.4)$ & $79(23.4)$ \\
\hline Associates & $103(10.3)$ & 66 (9.9) & $37(11.0)$ \\
\hline Bachelor's & $358(35.7)$ & $246(37.0)$ & $112(33.2)$ \\
\hline Graduate & $185(18.5)$ & $129(19.4)$ & $56(16.6)$ \\
\hline \multicolumn{4}{|l|}{ Employment status } \\
\hline Full time & $461(45.2)$ & $303(44.5)$ & $158(46.6)$ \\
\hline Part time & $170(16.7)$ & $115(16.9)$ & $55(16.2)$ \\
\hline Not employed & 389 (38.1) & $263(38.6)$ & $127(37.2)$ \\
\hline \multicolumn{4}{|l|}{ Marital status } \\
\hline Married & $414(40.6)$ & $273(41.2)$ & $139(41.0)$ \\
\hline Unmarried & $606(59.4)$ & $390(58.8)$ & $200(59.0)$ \\
\hline \multicolumn{4}{|l|}{ Religious } \\
\hline Yes & 387 (37.9) & $252(37.0)$ & $135(39.8)$ \\
\hline No & $543(53.2)$ & $361(53.0)$ & $182(53.7)$ \\
\hline Ambivalent & $90(8.8)$ & $68(10.0)$ & $22(6.5)$ \\
\hline \multicolumn{4}{|l|}{ Income } \\
\hline$<\$ 10,000$ & $167(16.4)$ & $115(16.9)$ & $52(15.3)$ \\
\hline$\$ 10,000-\$ 30,000$ & $234(22.9)$ & $154(22.6)$ & $80(23.6)$ \\
\hline$\$ 30,001-\$ 50,000$ & $220(21.6)$ & $137(20.1)$ & $83(24.5)$ \\
\hline$\$ 50,001-\$ 80,000$ & $201(19.7)$ & $131(19.2)$ & $70(20.7)$ \\
\hline$\$ 80,001-\$ 100,000$ & $63(6.2)$ & $42(6.2)$ & $21(6.2)$ \\
\hline$\$ 100,001-\$ 150,000$ & $91(8.9)$ & $71(10.4)$ & $20(5.9)$ \\
\hline$>\$ 150,000$ & $44(4.3)$ & $31(4.6)$ & $13(3.8)$ \\
\hline \multicolumn{4}{|l|}{ Location $^{*}$} \\
\hline Urban & $743(72.8)$ & $517(75.9)$ & $226(66.7)$ \\
\hline Rural & $277(27.2)$ & $164(24.1)$ & $113(33.3)$ \\
\hline
\end{tabular}

All values are listed as number (\%)

${ }^{*} p<0.05$.

Table 1. Demographic and baseline characteristics of respondents, overall and by shelter in place status. 


\begin{tabular}{|c|c|c|c|c|c|c|c|c|c|c|c|c|c|}
\hline & \multicolumn{13}{|l|}{ No. (\%) } \\
\hline & & Sex & & & Shelter in place & & & Location & & & Married & & \\
\hline Severity & Overall & Male & Female & & Yes & No & & Urban & Rural & & Yes & No & \\
\hline \multicolumn{14}{|l|}{ GAD-7 } \\
\hline None & $\begin{array}{l}472 \\
(47.9) \\
\end{array}$ & $\begin{array}{l}260 \\
(53.9) \\
\end{array}$ & $\begin{array}{l}212 \\
(42.2) \\
\end{array}$ & \multirow[t]{4}{*}{$P=0.002$} & 299 (45.9) & $172(52.1)$ & \multirow[t]{4}{*}{$P=0.314$} & 337 (47.5) & $134(49.5)$ & \multirow[t]{4}{*}{$P=0.041$} & $195(48.2)$ & $277(47.8)$ & \multirow[t]{4}{*}{$P=0.894$} \\
\hline Mild & $\begin{array}{l}249 \\
(25.3)\end{array}$ & $\begin{array}{l}111 \\
(23.0)\end{array}$ & $\begin{array}{l}138 \\
(27.4)\end{array}$ & & $172(26.4)$ & $76(23.0)$ & & $194(27.4)$ & $53(19.6)$ & & $106(27.2)$ & $143(24.7)$ & \\
\hline Moderate & $\begin{array}{l}132 \\
(13.4)\end{array}$ & $\begin{array}{l}60 \\
(12.5)\end{array}$ & $\begin{array}{l}72 \\
(14.3)\end{array}$ & & 89 (13.7) & $42(12.7)$ & & $93(13.1)$ & $39(14.4)$ & & $51(12.6)$ & $81(14.0)$ & \\
\hline Severe & $\begin{array}{l}132 \\
(13.4)\end{array}$ & $\begin{array}{l}51 \\
(10.6)\end{array}$ & $\begin{array}{l}81 \\
(16.1)\end{array}$ & & $92(14.1)$ & $40(12.1)$ & & 85 (12.0) & 45 (16.6) & & $53(13.1)$ & 79 (13.6) & \\
\hline \multicolumn{14}{|l|}{ PHQ-9 } \\
\hline None & $\begin{array}{l}518 \\
(52.7)\end{array}$ & $\begin{array}{l}278 \\
(58.3)\end{array}$ & $\begin{array}{l}240 \\
(47.4)\end{array}$ & \multirow[t]{4}{*}{$P=0.008$} & $340(52.2)$ & $176(53.3)$ & \multirow[t]{4}{*}{$P=0.457$} & $373(52.8)$ & $143(52.6)$ & \multirow[t]{4}{*}{$\mathrm{P}=0.714$} & 239 (59.9) & $279(47.8)$ & \multirow[t]{4}{*}{$P<0.0001$} \\
\hline Mild & $\begin{array}{l}233 \\
(23.7)\end{array}$ & $\begin{array}{l}102 \\
(21.4)\end{array}$ & $\begin{array}{l}131 \\
(25.9)\end{array}$ & & 149 (22.9) & $84(25.5)$ & & $165(23.4)$ & $68(25.0)$ & & $92(23.10$ & $141(24.1)$ & \\
\hline Moderate & $\begin{array}{l}116 \\
(11.8)\end{array}$ & $\begin{array}{l}48 \\
(10.1)\end{array}$ & $\begin{array}{l}68 \\
(13.4)\end{array}$ & & 84 (12.9) & $32(9.7)$ & & $114(11.7)$ & $27(9.9)$ & & $34(8.5)$ & $82(14.0)$ & \\
\hline Severe & $\begin{array}{l}116 \\
(11.8) \\
\end{array}$ & $\begin{array}{l}49 \\
(10.3)\end{array}$ & $\begin{array}{l}67 \\
(13.2) \\
\end{array}$ & & $78(12.0)$ & $38(11.5)$ & & $115(11.8)$ & 34 (12.5) & & $34(8.5)$ & $82(14.0)$ & \\
\hline
\end{tabular}

Table 2. Anxiety and depression severity, by selected baseline characteristics.

Abbreviations:

GAD-7: Generalized Anxiety Disorders scale

PHQ-9: Patient Health Questionnaire 
medRxiv preprint doi: https://doi.org/10.1101/2020.05.26.20114140; this version posted May 28, 2020. The copyright holder for this preprint (which was not certified by peer review) is the author/funder, who has granted medRxiv a license to display the preprint in perpetuity.

It is made available under a CC-BY-NC-ND 4.0 International license .

\begin{tabular}{|c|c|c|c|c|}
\hline & Unadjusted OR (95\% Cl) & $P$ value & Adjusted $^{\dagger}$ OR (95\% Cl) & P value \\
\hline \multicolumn{5}{|l|}{ GAD-7 (Anxiety) ${ }^{*}$} \\
\hline \multicolumn{5}{|l|}{ Sex } \\
\hline Male & $0.67(0.51,0.89)$ & 0.005 & $0.65(0.49,0.87)$ & 0.003 \\
\hline Female & 1 [Reference] & & 1 [Reference] & \\
\hline \multicolumn{5}{|l|}{ Location } \\
\hline Rural & $1.32(0.98,1.79)$ & 0.066 & $1.39(1.03,1.89)$ & 0.034 \\
\hline Urban & 1 [Reference] & & 1 [Reference] & \\
\hline \multicolumn{5}{|c|}{ Hospitalized in past 2 years } \\
\hline Yes & $1.86(1.27,2.73)$ & 0.001 & $2.04(1.38,3.03)$ & $<0.0001$ \\
\hline No & 1 [Reference] & & 1 [Reference] & \\
\hline \multicolumn{5}{|l|}{ Lost job due to COVID-19 } \\
\hline Yes & $1.61(1.05,2.45)$ & 0.028 & $1.53(0.99,2.35)$ & 0.055 \\
\hline No & 1 [Reference] & & 1 [Reference] & \\
\hline \multicolumn{5}{|l|}{ Loneliness (ULS-8) $^{\ddagger}$} \\
\hline Most lonely quartile & $5.39(3.53,8.24)$ & $<0.0001$ & $4.92(3.18,7.62)$ & $<0.0001$ \\
\hline Least lonely quartile & 1 [Reference] & & 1 [Reference] & \\
\hline \multicolumn{5}{|l|}{ Home size (square feet) } \\
\hline$<500$ & 1 [Reference] & & 1 [Reference] & \\
\hline $500-750$ & $0.59(0.32,1.12)$ & 0.107 & $0.60(0.31,1.14)$ & 0.120 \\
\hline $750-1000$ & $0.38(0.20,0.70)$ & 0.002 & $0.37(0.20,0.69)$ & 0.002 \\
\hline $1000-1500$ & $0.48(0.27,0.85)$ & 0.013 & $0.50(0.28,0.91)$ & 0.024 \\
\hline $1500-2000$ & $0.50(0.27,0.90)$ & 0.022 & $0.53(0.29,0.98)$ & 0.043 \\
\hline$>2000$ & $0.39(0.21,0.74)$ & 0.004 & $0.46(0.24,0.88)$ & 0.019 \\
\hline \multicolumn{5}{|l|}{ PHQ-9 (Depression) ${ }^{*}$} \\
\hline \multicolumn{5}{|l|}{ Sex } \\
\hline Male & $0.73(0.55,0.98)$ & 0.034 & $0.71(0.53,0.95$ & 0.023 \\
\hline Female & 1 [Reference] & & 1 [Reference] & \\
\hline \multicolumn{5}{|l|}{ Location } \\
\hline Rural & $0.90(0.65,1.24)$ & 0.515 & $0.94(0.67,1.30)$ & 0.700 \\
\hline Urban & 1 [Reference] & & 1 [Reference] & \\
\hline \multicolumn{5}{|c|}{ Hospitalized in past 2 years } \\
\hline Yes & $2.16(1.47,3.17)$ & $<0.0001$ & $2.42(1.62,3.62)$ & $<0.0001$ \\
\hline No & 1 [Reference] & & 1 [Reference] & \\
\hline \multicolumn{5}{|l|}{ Lost job due to COVID-19 } \\
\hline Yes & $1.74(1.13,2.67)$ & 0.011 & $1.64(1.05,2.54)$ & 0.029 \\
\hline No & 1 [Reference] & & 1 [Reference] & \\
\hline \multicolumn{5}{|l|}{ Loneliness (ULS-8) $^{\ddagger}$} \\
\hline Most lonely quartile & $11.90(7.21,19.65)$ & $<0.0001$ & $10.42(6.26,17.36)$ & $<0.0001$ \\
\hline Least lonely quartile & 1 [Reference] & & 1 [Reference] & \\
\hline \multicolumn{5}{|l|}{ Home size (square feet) } \\
\hline$<500$ & 1 [Reference] & & 1 [Reference] & \\
\hline $500-750$ & $0.50(0.26,0.94)$ & 0.033 & $0.50(0.26,0.96)$ & 0.037 \\
\hline $750-10000$ & $0.41(0.22,0.76)$ & 0.004 & $0.40(0.22,0.76)$ & 0.005 \\
\hline $1000-1500$ & $0.42(0.23,0.76)$ & 0.004 & $0.45(0.25,0.83)$ & 0.010 \\
\hline $1500-2000$ & $0.35(0.19,0.65)$ & 0.001 & $0.38(0.20,0.72)$ & 0.003 \\
\hline$>2000$ & $0.29(0.15,0.56)$ & $<0.0001$ & $0.35(0.18,0.69)$ & 0.002 \\
\hline \multicolumn{5}{|c|}{$\begin{array}{l}\text { Time spent outdoors in past } 3 \text { days } \\
\text { (hours) }\end{array}$} \\
\hline 0 & 1 [Reference] & & 1 [Reference] & \\
\hline
\end{tabular}


medRxiv preprint doi: https://doi.org/10.1101/2020.05.26.20114140; this version posted May 28, 2020. The copyright holder for this preprint (which was not certified by peer review) is the author/funder, who has granted medRxiv a license to display the preprint in perpetuity.

It is made available under a CC-BY-NC-ND 4.0 International license .

\begin{tabular}{|l|l|l|l|l|}
\hline$<1$ & $0.77(0.47,1.27)$ & 0.302 & $0.80(0.48,1.34)$ & 0.398 \\
\hline $1-3$ & $0.55(0.34,0.88)$ & 0.014 & $0.58(0.35,0.95)$ & 0.031 \\
\hline $3-5$ & $0.45(0.24,0.82)$ & 0.010 & $0.53(0.28,0.98)$ & 0.044 \\
\hline$>5$ & $0.45(0.25,0.79)$ & 0.006 & $0.51(0.29,0.92)$ & 0.025 \\
\hline
\end{tabular}

${ }^{*}$ Score cutoff of 10 used for classification.

${ }^{\dagger}$ Adjusted for age and sex.

${ }^{\ddagger}$ Assessed using the UCLA Loneliness Scale

Abbreviations:

GAD-7: Generalized Anxiety Disorders scale

PHQ-9: Patient Health Questionnaire

Table 3. Risk factors for anxiety and depression in unadjusted and multivariable analyses. 